\title{
Performance Evaluation of Collaborative Innovation of Industry, University and Research Institute in China
}

\author{
Zhu Xuangong, ${ }^{1}{ }^{1}$, Wang Ning ${ }^{1, b}$ \\ ${ }^{1}$ School of Management Henan University of Science and Technology Luo yang, China
}

\begin{abstract}
As an important form of technological innovation, the collaborative innovation of industry-university-research institute has attracted more and more attention from the business circles, science and technology management departments and academic circles in China. Against this background, the performance evaluation model of industry-university-research collaboration innovation was established on the basis of the input-output perspective, and the factor analysis was used to scientifically assess the performance of industry-university-research collaboration innovation in 29 provinces and cities in China. The scores and rankings were analyzed in detail.
\end{abstract}

\section{Literature review}

Regarding the evaluation of the collaborative innovation performance of industry-university-research institutes, the research direction of domestic and foreign scholars mainly focuses on the measurement and the improvement path of collaborative innovation performance of industry-university-research institute. In the late 1980s, Grander (1982), an American economist, first adopted the method of mathematical analysis to conduct a detailed mathematical description and process analysis of the industry-university-research cooperation behavior from the perspective of universities and commercial activities. Fritsch and Slavtchev (2006) used the knowledge production function method to evaluate the efficiency of the regional innovation system by taking the $R \& D$ expenditure of a specific region as the input, and the number of patents obtained as the output. In addition, Khodabaskhshi (2010) and other researchers verified the random and fuzzy data envelope models, which provided a method for the DEA method to estimate the benefits in proportion.

It has to be admitted that Chinese scholars are relatively late to study the performance of industry-university-research collaboration innovation. In 1999, Li Daguang and Cui Yingde used the analytic hierarchy process to conduct the earliest research on the performance evaluation of industry-university-research integration. Subsequently, Fan Decheng and Tang Xiaoxu
(2009) evaluated the innovation performance of industry-university-research in 30 provinces and cities in China. Based on the application of data envelopment analysis, Zhu Lili (2012) analyzed the performance of industry-university-research collaborative innovation in Anhui Province, and put forward suggestions for performance improvement. These studies are of great significance to promote collaborative innovation between industry-university-research institutes. However, due to the complexity and uncertainty, there are still many difficulties in grasping and elaborating industry-university-research collaborative innovation in a comprehensive and accurate way, which requires more scholars to do further in-depth research.

\section{Construction of indicator system}

Under the framework of system theory, industry-university-research collaborative innovation belongs to an "input-output" system. Subject to the external environment, innovative subjects invest in human resources, material resources and financial resources. The interplay of the three parties reinforces the cooperation and facilitates the transition of innovation effects to the collaborative innovation output of industry-university-research institutes. Consequently, the paper divides collaborative innovation assessment indicators for industry-university-research institutes into input and output. Assessment indicator system is as shown in Table 1.

Table 1 Performance Evaluation System of Industry-University-Research Collaborative Innovation

\begin{tabular}{ccc}
\hline Target & $\begin{array}{c}\text { Primary } \\
\text { indicator }\end{array}$ & Secondary indicator \\
\hline Performance & Industry-Univer & X1: Number of university R\&D personnel / person \\
Evaluation of & sity-Research & X2: Internal expenditure of university R\&D funds / 10,000 yuan \\
Industry-Unive & Collaborative & X3: Number R\&D personnel of R\&D institution personnel / person
\end{tabular}

axg@@haust.edu.cn b18539747923@163.com 
rsity-Research

Collaborative

Innovation
Innovation Input

(a)

Industry-Univer sity-Research Collaborative Innovation Output

X4: Internal expenditure of R\&D institutions / 10,000 yuan

X5: Number of R\&D personnel of industrial enterprises above designated size/ person

X6: Internal expenditure of R\&D funds of industrial enterprises above designated size / 10,000 yuan

X7: Internal expenditures for R\&D cooperation between R\&D institutions and enterprises / 10,000 yuan

X8: Internal expenditures for R\&D cooperation between R\&D institutions and government / 10,000 yuan X9: Internal Expenditure for R\&D Expenditure of industrial enterprises above designated size and government/ 10,000 yuan

X10: Proportion of university R\&D funds from corporate funds / \%

X11: Proportion of university R\&D funds from government funds / \%

Y1: Number of scientific papers of universities / articles

Y2: Number of effective inventions in university / pieces

Y3: Number of scientific papers of research institutions/ articles

Y4: Number of effective inventions in R\&D institutions / pieces

Y5: Number of new product development projects of industrial enterprises above designated size / items Y6: Number of effective inventions of industrial enterprises above designated size / pieces

Y7: Sales revenue of new products of industrial enterprises above designated size / 10,000 yuan

Y8: Technology market turnover / 10,000 yuan

In the input indicator of industry-university-research collaboration innovation, the number of $R \& D$ personnel in universities, $\mathrm{R} \& \mathrm{D}$ institutions, and industrial enterprises above designated size refers to the number of personnel involved in the innovation-research collaboration among the various innovation subjects, reflecting their input capabilities and potential for personnel involved in collaborative innovation. The internal expenditures of R\&D funds of universities, R\&D institutions, and industrial enterprises above designated size refer to the funds invested by various innovation entities in the collaborative innovation of industry-university-research institutes, which reflects their capital investment capacity and potential to participate in collaborative innovation. According to the amount and proportion of cooperation funds, the indicators $\mathrm{X} 7, \mathrm{X} 8, \mathrm{X} 9, \mathrm{X} 10$, and $\mathrm{X} 11$ reflect the closeness of cooperation between innovation entities.

There exist eight indicators suggesting the collaborative innovation output of industry-university-research institutes. Among all of these factors, the quantity of technical papers issued by universities, research institutes reflects the fruits of academic innovation. The abundance of inventions in universities, research institutes also reflects the ownership and innovative values of intellectual property and research results. Moreover, the Number of new product development projects of industrial enterprises above designated size, as the most straightforward outputs throughout corporate collaborative innovation process, shows the activity degree and direct outcome of collaborative innovation. As mentioned above, the number of inventions owned by industrial enterprises above designated size on the other hand proves the research and development intensity of the organization. The sales volume brought about by new products in industrial companies above scale demonstrates the benefits gained by industry-university-research institutes from collaborative innovation. This is the foremost impetus of collaborative innovation and also industrialization among industry-university-research institutes. The turnover in the technology market indicates the degree of commoditization and industrialization of the collaborative innovation of industry, university and research institute.

\section{Empirical analysis}

The statistical data in this article comes from China Statistical Yearbook and China Science and Technology Statistical Yearbook. Given that there exists a time lag between the input of innovation resources and the output of innovation achievements, and referring to the research of existing scholars, the lag period is determined as one year in this paper. That is to say, the input of the collaborative innovation of industry-university-research institutes uses the data of relevant statistical yearbook in 2017, and the output indicators of collaborative innovation of industry-university-research institutes use the data of relevant statistical yearbooks in 2018, which is more practical and objective. Because of the lack of some index data in Tibet and Ningxia, they were excluded from the study.

Software SPSS20.0 was selected to process the indicator data. First, the original data is standardized to eliminate the effects of dimensions and orders of magnitude. As shown in Table 2, the KMO value of the data in this article is 0.707 , and the partial correlation between variables is strong, which meets the requirements of factor analysis. At the same time, the significance of the data in this paper has passed the Bartlett sphericity test with a level of 0.05 , indicating that factors can be used for analysis in this paper

Table $2 \mathrm{KMO}$ and Bartlett's test

\begin{tabular}{llc}
\hline Kaiser-Meyer-Olkin measure of sample adequacy. & 0.707 \\
\hline Bartlett's sphericity test & Approximate chi-square & 1194.354 \\
& $\mathrm{~d} f$ & 171 \\
\hline
\end{tabular}


Sig.

0.000

The maximum rotation of variance is adopted to perform factor rotation. Table 3 shows the total variance interpreted by the extracted factors and their proportions. According to the principle that the eigenvalue is greater than 1, three common factors were extracted after dimensionality reduction, with contribution rates of $46.634 \%, 32.950 \%$ and $13.019 \%$, respectively. There is $92.602 \%$ of the information in the indicator, and the loss of information is small.

Table 3 Total variance explained

\begin{tabular}{cccccccccc}
\hline \multirow{2}{*}{$\begin{array}{c}\text { Ingredie } \\
\text { nts }\end{array}$} & \multicolumn{3}{c}{ Initial eigenvalue } & \multicolumn{3}{c}{ Extract square sum load } & \multicolumn{3}{c}{ Rotated square sum loading } \\
\cline { 2 - 10 } & total & $\begin{array}{c}\text { variance } \\
\%\end{array}$ & $\begin{array}{c}\text { accumulat } \\
\text { ion\% }\end{array}$ & total & $\begin{array}{c}\text { variance } \\
\%\end{array}$ & $\begin{array}{c}\text { accumul } \\
\text { ation\% }\end{array}$ & total & $\begin{array}{c}\text { variance } \\
\%\end{array}$ & $\begin{array}{c}\text { accumul } \\
\text { ation\% }\end{array}$ \\
\hline 1 & 10.955 & 57.866 & 57.866 & 10.995 & 57.866 & 57.866 & 8.860 & 46.634 & 46.634 \\
2 & 4.766 & 25.085 & 82.581 & 4.766 & 25.085 & 82.581 & 6.260 & 32.950 & 79.583 \\
3 & 1.834 & 9.651 & 92.602 & 1.834 & 9.651 & 92.602 & 2.474 & 13.019 & 92.602 \\
\hline
\end{tabular}

In the process of factor analysis, factor rotation is often carried out to better name and account for the extracted common factor. The processed rotation component matrix reflects the degree to which each factor explains the original variable after rotation. Factors are more practical and convenient to analyze practical problems. In this paper, the maximum variance method is adopted for factor rotation. Table 4 presents the factor load matrix after rotation:

Table 4 Rotation component matrix

\begin{tabular}{|c|c|c|c|}
\hline & \multicolumn{3}{|c|}{$\begin{array}{l}\text { ingre } \\
\text { dient }\end{array}$} \\
\hline & 1 & 2 & 3 \\
\hline Y4: Number of effective inventions in R\&D institutions / pieces & 0.990 & & \\
\hline X4: Internal expenditure of R\&D institutions / 10,000 yuan & 0.982 & & 0.126 \\
\hline Y3: Number of scientific papers of research institutions / articles & 0.981 & & \\
\hline X3:Number of R\&D personnel of R\&D institution personnel / person & 0.977 & & 0.151 \\
\hline $\begin{array}{l}\text { X8: Internal expenditures for R\&D cooperation between R\&D institutions and government / 10,000 } \\
\text { yuan }\end{array}$ & 0.976 & & 0.120 \\
\hline Y8: Technology market turnover / 10,000 yuan & 0.970 & 0.112 & \\
\hline X7: Internal expenditures for $R \& D$ cooperation between $R \& D$ institutions and enterprises / 10,000 yuan & 0.919 & 0.180 & 0.228 \\
\hline X2: Internal expenditure of university R\&D funds / 10,000 yuan & 0.775 & 0.517 & 0.232 \\
\hline Y2: Number of effective inventions in university/pieces & 0.752 & 0.471 & 0.276 \\
\hline Y1: Number of scientific papers of universities / articles & 0.689 & 0.567 & 0.362 \\
\hline X1: Number of university R\&D personnel / person & 0.659 & 0.616 & 0.311 \\
\hline Y7: Sales revenue of new products of industrial enterprises above designated size / 10,000 yuan & & 0.989 & \\
\hline X5: Number of R\&D personnel in industrial enterprises above designated size/ person & & 0.976 & 0.103 \\
\hline X6: Internal expenditure of R\&D funds of industrial enterprises above designated size / 10,000 yuan & & 0.968 & \\
\hline Y5: Number of new product development projects of industrial enterprises above designated size/ items & & 0.968 & \\
\hline Y6: Number of effective inventions of industrial enterprises above designated size / pieces & 0.113 & 0.914 & \\
\hline $\begin{array}{l}\text { X9:Internal Expenditure for R\&D Expenditure of industrial enterprises above designated size and } \\
\text { government/ 10,000 yuan }\end{array}$ & 0.324 & 0.589 & 0.473 \\
\hline X10: Proportion of university R\&D funds from government funds / \% & & & 0.950 \\
\hline X11: Proportion of university R\&D funds from corporate funds / \% & 0.217 & & 0.945 \\
\hline
\end{tabular}

As can be seen from Table 4, the indicators $Y 4, X 4$, $\mathrm{Y} 3, \mathrm{X} 3, \mathrm{X} 8, \mathrm{Y} 8, \mathrm{X} 7, \mathrm{X} 2, \mathrm{Y} 2, \mathrm{Y} 1$, and X1 have a larger load on the common factor 1 , which jointly reflects the input and output of universities and $R \& D$ institutions. Therefore, the common factor 1 is referred to as the innovation capacity factor of universities and R\&D institutions.

In the common factor 2, the factors with higher factor load are Y7, X5, X6, Y5, Y6, and X9, which reflect the ability of enterprises to participate in collaborative innovation. As a result, the common factor 2 is called as the enterprise's innovation capability factor.
In the common factor 3 , the indicators X10 and X11 reflect the closeness of cooperation between universities, governments, and enterprises. Therefore, the common factor 3 is called the industry-university-research collaboration innovation synergy factor.

The contribution rate of each common factor was divided by $92.602 \%$ of the total factor contribution rate to obtain the weight of each common factor. For convenience, the common factors 1, 2, and 3 are expressed as F1, F2, and F3, respectively. The weight coefficients of F1, F2, and F3 are $50.36 \%, 35.58 \%$, and $14.06 \%$, respectively. The comprehensive evaluation model of the collaborative innovation performance of 
various provinces and cities is as follows:

$$
F=50.36 \% * F 1+35.58 \% * F 2+14.06 \% * F 3
$$

By substituting the scores of each common factor into the above formula, the comprehensive evaluation scores of the innovation performance of industry-university-research cooperation of all provinces and cities in China can be calculated. The specific situation is shown in Table 5:

Table 5 Comprehensive evaluation scores of collaborative innovation performance of industry, university and research in various provinces and cities in China

\begin{tabular}{|c|c|c|c|}
\hline $\begin{array}{c}\text { Provinces and } \\
\text { cities }\end{array}$ & F1 score & Ranking & F2 score \\
\hline Beijing & 4.885 & 1 & -0.611 \\
\hline Jiangsu & 0.396 & 5 & 2.568 \\
\hline Guangdong & -0.060 & 7 & 3.469 \\
\hline Shanghai & 0.976 & 2 & 0.178 \\
\hline Zhejiang & -0.268 & 13 & 1.413 \\
\hline Shandong & -0.164 & 9 & 1.397 \\
\hline Sichuan & 0.406 & 3 & -0.415 \\
\hline Hubei & 0.174 & 6 & 0.123 \\
\hline Shaanxi & 0.397 & 4 & -0.364 \\
\hline Liaoning & -0.087 & 8 & -0.376 \\
\hline Hunan & -0.305 & 17 & 0.101 \\
\hline Anhui & -0.165 & 10 & 0.319 \\
\hline Tianjin & -0.203 & 12 & -0.242 \\
\hline Henan & -0.335 & 20 & -0.029 \\
\hline Heilongjiang & -0.462 & 26 & -0.600 \\
\hline Fujian & -0.306 & 18 & 0.064 \\
\hline Hebei & -0.367 & 23 & -0.222 \\
\hline Chongqing & -0.535 & 29 & -0.377 \\
\hline Jilin & -0.168 & 11 & -0.468 \\
\hline Jiangxi & -0.523 & 27 & -0.463 \\
\hline Guangxi & -0.321 & 19 & -0.469 \\
\hline Yunnan & -0.276 & 14 & -0.567 \\
\hline Shanxi & -0.359 & 22 & -0.548 \\
\hline Gansu & -0.428 & 24 & -0.839 \\
\hline Guizhou & -0.443 & 25 & -0.611 \\
\hline $\begin{array}{c}\text { Inner } \\
\text { Mongolia }\end{array}$ & -0.529 & 28 & -0.642 \\
\hline Xinjiang & -0.276 & 15 & -0.565 \\
\hline Hainan & -0.350 & 21 & -0.644 \\
\hline Qinghai & -0.304 & 16 & -0.581 \\
\hline
\end{tabular}

\section{Conclusion}

The performance evaluation system of collaborative innovation of industry-university-research institutes constructed in this paper is universal, which conforms to the actual situation in various regions of China. There are three parts in the performance evaluation system of collaborative innovation of industry-university-research institutes, that is, the innovation capabilities of universities and R\&D institutions, the innovation capabilities of enterprises, and the industry-university-research collaboration innovation synergy factor. The positive and negative scores of the common factor scores and comprehensive evaluation scores in Table 5 have no practical significance, which only reflects the relative relationship between the collaborative innovation performance of

\begin{tabular}{|c|c|c|c|c|}
\hline anking & F3 score & Ranking & overall ratings & $\begin{array}{c}\text { total } \\
\text { ranking }\end{array}$ \\
\hline 26 & -0.592 & 22 & 2.160 & 1 \\
\hline 2 & 0.528 & 7 & 1.187 & 2 \\
\hline 1 & -0.812 & 25 & 1.090 & 3 \\
\hline 6 & 0.618 & 6 & 0.642 & 4 \\
\hline 3 & 0.467 & 8 & 0.433 & 5 \\
\hline 4 & -0.247 & 17 & 0.380 & 6 \\
\hline 16 & 2.158 & 1 & 0.360 & 7 \\
\hline 7 & 0.462 & 10 & 0.196 & 8 \\
\hline 13 & 0.826 & 5 & 0.187 & 9 \\
\hline 14 & 1.812 & 2 & 0.077 & 10 \\
\hline 8 & 0.423 & 12 & -0.058 & 11 \\
\hline 5 & -0.842 & 26 & -0.088 & 12 \\
\hline 12 & 0.464 & 9 & -0.123 & 13 \\
\hline 10 & 0.246 & 13 & -0.144 & 14 \\
\hline 24 & 1.711 & 3 & -0.206 & 15 \\
\hline 9 & -0.688 & 24 & -0.228 & 16 \\
\hline 11 & 0.153 & 15 & -0.242 & 17 \\
\hline 15 & 1.003 & 4 & -0.263 & 18 \\
\hline 18 & -0.542 & 20 & -0.327 & 19 \\
\hline 17 & 0.207 & 14 & -0.399 & 20 \\
\hline 19 & -0.643 & 23 & -0.419 & 21 \\
\hline 22 & -0.566 & 21 & -0.420 & 22 \\
\hline 20 & -0.530 & 19 & -0.450 & 23 \\
\hline 29 & 0.446 & 11 & -0.451 & 24 \\
\hline 25 & -0.502 & 18 & -0.511 & 25 \\
\hline 27 & -0.206 & 16 & -0.524 & 26 \\
\hline 21 & -1.591 & 27 & -0.564 & 27 \\
\hline 28 & -1.600 & 28 & -0.630 & 28 \\
\hline 23 & -2.164 & 29 & -0.664 & 29 \\
\hline
\end{tabular}

industry-university-research institutes in various innovation performance of provinces and cities with a comprehensive score greater than 0 is higher than the national average, while that of provinces and cities with a comprehensive score less than 0 is lower than the national average. In general, the performance of industry-university-research collaborative innovation in China is not satisfactory, and only 10 provinces and cities have higher collaborative innovation performance than the national average. In addition, the provinces and cities have obvious regional characteristics. There is an obvious gap between the economically backward western region and the economically developed eastern region. For example, Beijing's comprehensive score is 2.160 , which is much higher than other provinces and cities in China. Finally, with the exception of Beijing and Jiangsu, there was little difference in total scores for the neighboring regions in the remaining ranks. 


\section{Acknowledgement}

This thesis is a major project of applied research in philosophy and social science in higher education institutions in Henan Province: a study on the impact of regional collaborative innovation on industrial transformation and upgrading ---- Taking the six central provinces as an example (2020-YYZD-05), as well as the social science planning in Henan Province Subject: Research on the evolution of employment agencies in Henan Province under the background of industrial structure upgrade (2019BJJ029).

\section{References}

1. University-Industry Research Relationship. National Science Foundation. J.P.Grander. Research Polity. 1982

2. An additive model approach for estimating returns to scale inimprecise data envelopment analysis. MKHODABAKHSHI,Y GHOLAMI,HKHEIROLLAHI. Applied Mathe-matical Modelling. 2010

3. What Determines the Efficiency of Regional Innovation Systems?. Fritsch, Michael,Slavtchev, Viktor. Jena Economic Research Paper No.2007-006. 2007

4. Li Daguang, Cui Yingde, Cai Libin, Song Qihuang. Application of analytic hierarchy process in the benefit evaluation of the combined model of industry, university and research [J]. Guangzhou Chemical Industry, 1999 (04): 85-89 + 92.

5. Fan Decheng, Tang Xiaoxu. Performance evaluation of technology innovation combining production, teaching and research in various provinces and cities in China [J]. Science of Science and Technology Management, 2009, 30 (01): 66-70.

6. Research on Performance Evaluation of Anhui Province Industry-University-Research Cooperation [D]. Zhu Lili. Anhui University. 2012 